\title{
Can Integrated Water Resources Management contribute to sustainable peace in the Middle East?
}

\author{
Khaldoon A. Mourad ${ }^{1}$, Ronny Berndtsson ${ }^{2}$, Karin Aggestam ${ }^{3}$ \\ ${ }^{1}$ Department of Water Resources Engineering, Lund University, Lund, Sweden \\ ${ }^{2}$ Center for Middle Eastern Studies, Lund University, Lund, Sweden \\ ${ }^{3}$ Department of Political Science, Lund, Sweden \\ Email: khaldoonmourad@yahoo.com
}

Received January 30, Year (2013).

\begin{abstract}
Water resources issue in the Middle East is an important question related to the $4^{\text {th }}$ June 1967 line in the Middle East peace process. This paper focuses on possibilities within the Integrated Water Resources Management (IWRM) approach to contribute to the peace process between what is called Israel and Arab countries emphasizing fruitful cooperation to resolve the $4^{\text {th }}$ June 1967 line issue. The paper shows that start of a possible cooperation could be founded on interest-based negotiations and built on IWRM principles by a simple geographical allocation plan for the Lake Tiberias water together with a joint environmental protection plan to build cooperation instead of confrontation and integration instead of fragmentation. In a better cooperative climate, withdrawing from the $4^{\text {th }}$ June 1967 line could be a possibility because negotiation results would incur safer access to sustainable water resources and a comprehensive peace.
\end{abstract}

Keywords: Lake Tiberias; Negotiations; Comprehensive peace

\section{Introduction}

Due to water scarcity, lack of water management and regional cooperation, Middle East (ME) is considered a hot spot in terms of water shortage and security. Water shortage has affected regional relationships between countries and their policies, especially in arid and semiarid regions. Hence, many water-related problems could become more serious in the near future, especially after realizing the absence of the UN in solving such problems or implementing its resolutions (242 and 338 resolutions are good examples). In this regard, history has shown that lack of freshwater supply may lead to instability that in turn creates political conflicts within shared water resources. In January 2005, 18 people died in a clash between two ethnic groups in southern Sudan over utilizing common rivers (Juizo, Liden, \& Vaz, 2006). After his visit to Darfur in 2007, the UN Secretary General Ban Ki-Moon stated that 'Darfur is an environmental crisis - a conflict that grew at least in part from desertification, ecological degradation and a scarcity of resources, foremost among the water (Zeitoun \& Mirumachi, 2008). Access to and control of Shatt-al-Arab waterway was one reason that led to the eight-year war between Iraq and Iran (1980-1988) (Workman, 1991). Moreover, water has been the roots, means, and causes of war in the Jordan River basin (Mimi \& Sawalhi, 2003). In 1953, the state of Israel (IS) made concrete plans to divert Jordan River and to pump water from Lake Tiberias by construction of the National Water Carrier (NWC) at northern parts of Lake Tiberias. This resulted in Syria protesting to the United Nation (UN). The UN, in turn, made IS changing the intake place of the carrier in 1954 (Smith, 1966). The U.S. president, Eisenhower, sent Eric Johnston to solve the water issue in the region. After his first proposal for water allocation and under the objections of the Arab states,
Johnston proposed a unified plan as follows: 400 MCM (million cubic meters) for IS, 720 MCM for Jordan, 35 MCM for Lebanon, and 132 MCM for Syria. Although the plan was accepted it was not ratified and countries in the region have continued to develop their water resources ignoring other countries' needs (Brooks, 1994; Wolf, 1996; Murakami, 1995).

In 1964 IS had completed its NWC, which pumps an annual water amount of 440 MCM for domestic use; another 100 MCM are pumped every year for agriculture purposes (Courcier et al., 2005). In March, May, and August 1965 the Israeli army attacked the diversion works in Syria, which was one among other causes for 1967 war (Cooley, 1984). After the 1967 war IS controlled half of the length of the Yarmouk River (80 km), compared to $10 \mathrm{~km}$ before the war (Murakami, 1995). Moreover, in the 1967 war the Israeli army destroyed more than 140 Palestinian wells (Humphries, 2006), which again indicates that water was the most important factor leading to the war (Brooks, 1994). Furthermore, the Israeli occupation of Golan Heights and the 1982 Israeli invasion of Lebanon have given IS a full control of the Jordan River flow and have increased their fresh water supplies by almost $50 \%$, especially when they included Hasbani and Wazzani rivers in their security zone (Hewedy, 1989). IS also aimed, during the 1982 invasion, at capturing the Litani water and directing it into the occupied lands (Cooley, 1984).

Acknowledging the finite water resources in the ME region, countries should focus towards new water allocation approaches and strategies in order to meet the growing water demand in a sustainable way, which leads to Integrated Water Resources Management (IWRM). IWRM ensures that social, economic, environmental, and technical dimensions are taken into account in the manage- 
ment and development of water resources. IWRM is based on bridging the gap between agreed policies and implementation (Rahaman \& Varis, 2005). Gaps between the participatory principle and its implementation in practice were exemplified by Petit and Baron (2009) for Burkina Faso. They found that social environments are characterized by strong hierarchic relationships that may hinder a rational IWRM approach. In studying the Mhlatuze catchment in South Africa, Funke et al. (2007) found that due to insufficient alignment and cooperation between the policies of different government departments and the practices of different water use sectors that impact on water, many institutional challenges persist. Therefore, it is vital to integrate water sub-sectors such as hydropower, water supply and sanitation, agriculture, and environment with the social dimension in the management process. Water policy, for example, plays a vital role in IWRM. It controls the water use in each country through a set of laws, policies, and legislations. Many countries face a multitude of problems in implementing their water policies and laws because they did not implement the participatory approach while setting their projects. For Lake Tiberias and the northern Jordan River, any IWRM policy that aims at resolving the present hydrological, ecological and political problems should take water quality and water quantity into consideration (Berman, 1998). This should be enhanced by public awareness and organization development in the region due to the importance of local participation in all water projects. Riparian countries, water user groups and individuals should realize that they all depend on each other now and in the future. This should lead to the building of institutional linkages that reciprocate and mirror the water flows in the upstream-downstream context, which is the base of any IWRM approach (Savenije \& Van der Zaag, 2008).

In view of the above; the objectives of this study were to analyze the $4^{\text {th }}$ June 1967 line issue in the ME and to suggest an IWRM approach that can be a starting point for sustainable peace in the ME. An IWRM approach would ensure the integration of all sectors and stakeholders at regional and international levels to realize justice and comprehensive peace and to achieve stability and security to the region. This is a formidable task that cannot be resolved in a single paper. However, we suggest a solution to the issue of the Lake Tiberias by a simple approach. This together with a comprehensive environmental protection plan of the Lake with surroundings and water saving demonstration project involving several villages in an international context could be a starting point for further international collaboration. Consequently, the paper starts off by giving a resume of water agreements and the peace process in the ME. After this, we outline important aspects of the IWRM for the area. Finally, we suggest an approach based on IWRM and a starting point by settling the Lake Tiberias issue.

\section{Water Conflicts in the ME}

The most important water conflicts in the ME are concentrated in the shared water basins between Syria, Lebanon, Jordan, and Palestine on one hand and IS on the other hand. This conflict axis is considered the most dangerous in the world because of its political conditions. "When it comes to the common water resources shared with Palestinians and other Arabs, Israel ... acts like a great sponge" (Elmusa 1993). Jordan River has three watercourses: Hasbani in Lebanon, Banias in Syria, and Dan in IS (Zeitoun et al., 2009; Fig. 1). They join together and flow into the Tiberias Lake. The Yarmouk River, with a total length about 360 $\mathrm{km}$, starts in Syria then joins Jordan River, and discharges in to the Dead Sea (Daoudy, 2008). After the 1967 war IS prohibited Arabs on the West Bank from drilling new wells without its permission, which was almost impossible. In a report to the Center for Strategic and International Studies in Washington D.C., Starr \& Stoll (1987) noted that water resources are exploited up to 4.5 and $95.5 \%$ in the West Bank and IS, respectively. IS also began to use between $50-75 \%$ of the Jordan River flow. On the other hand, the Tiberias Lake (Sea of Galilee) is considered the most sensitive lake in the region. Consequently, it appears clear that occupying the Syrian Golan Heights by IS was not for security reasons. Instead it had a water resources dimension. IS could, by occupying Golan Heights, control all water resources that supply Jordan River and Lake Tiberias, in addition to its control of some parts of Yarmouk River.

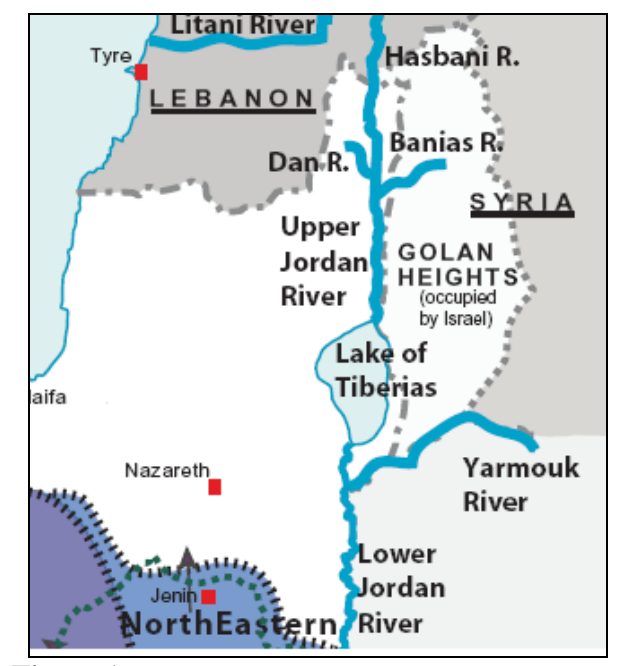

Figure 1.

Water resources supplying Lake Tiberias (after Zeitoun et al., 2009).

\section{Bilateral Water Agreements}

\subsection{Syria and Jordan}

On the third of September 1987 Syria and Jordan signed the Yarmouk river agreement that said; the two countries have right to water and electricity from the river by building the Unity Dam and to use its lake. Jordan will construct the $100 \mathrm{~m}$ high Unity Dam and Syria has the right to use all springs that originate from its land in Yarmouk basin except those upstream the dam with water level less than $250 \mathrm{~m}$, and Jordan has the right of using water that flows from the dam and from the producing electricity center (MOI-SY, 2008). Later on and after extended negotiations, on the $24^{\text {th }}$ of November 1998, Syria and Jordan signed the Yarmouk river water agreement with full focus on constructing the Unity Dam. The Syrian-Jordanian committee discussed the Copyright (C) 2013 SciRes. 
cost of the Unity Dam project in light of a new study presented by the Jordanian side.

\subsection{Jordan and IS}

In 1994 IS signed a peace agreement with Jordan. Water was a major issue in this agreement. Both countries agreed upon that IS will take $25 \mathrm{MCM} /$ year (12 MCM in summer and 13 MCM in winter) from Yarmouk River. IS, moreover, will transfer $20 \mathrm{MCM} /$ year from Jordan River in the summer period. Jordan, on the other hand, can take an annual quantity of $10 \mathrm{MCM}$ of desalinated water from about 20 MCM of saline springs that are diverted to the Jordan River, while operation and maintenance costs are financed by IS. The two countries agreed on establishing a Joint Water Committee of three members from each country that may have a number of specialized sub-committees for solving technical tasks and water management (Jägerskog, 2003).

\subsection{Palestinian Authority and IS}

In article 40 of the Oslo II Interim Agreement in September 1995, IS acknowledged, for the first time, the Palestinian water rights. The agreement formed a Joint Water Committee to discuss water shares and needs. The article also acknowledged the Palestinian future water needs on the West Bank to be between 70-80 MCM/year (Jägerskog, 2003).

\section{Negotiations in the ME Peace Process}

\subsection{General about the peace process}

The Middle East peace process was launched at the Madrid conference October 31, 1991. Within this process five multilateral working groups were set up to complement the bilateral negotiations covering water resources, environment, arms control and regional security, refugees, and regional economic development (Haddadin, 2002). Due to the fact that about $55 \%$ of Israel's total water supply comes from non-Israeli sources, 280 MCM from Golan Heights, 415 MCM from the West Bank, and 215 MCM from Lebanon, Syria, and Jordan (Zarour, 1992), Israel had from the beginning of the Middle East talks insisted on a full cooperation on water projects in a regional framework. The complexity of the water issue in the Middle East creates conflicts that require experts and mediators to be involved in the negotiation approach. Conflicts are resolved by negotiation. In general, negotiations can be right-based, power-based, or interest-based. The right-based approach has not worked for more than sixty years and it will not be, by itself, the way to resolve the conflicts in the Middle East, because Israel refused to admit or to apply the United Nation resolutions (242 and 338). The power-based approach, on the other hand, means resolving the conflicts for the powerful side interests, which is not the way to resolve conflicts in the Middle East where Arabs and Israel have had many wars since 1948 (i.e., 1967, 1973, 1979, and 1982). Moreover, the last two wars against Lebanon in 2006 and Palestine in 2008 have shown that power will not bring a sustainable peace, it has brought destruction and hate to human beings inside and outside the region. Power also allows the con- flicts to recur. Therefore, interest-based negotiations, which look for equal needs and concerns of the parties (depending on why and not only what) is the best approach to solve water conflicts in the Middle East. In this mixed approach, problems will be solved at a regional level and many options can be developed to reach the best agreement.

\subsection{Tiberias Lake (Sea of Galilee)}

Tiberias Lake is located between Syria and Palestine at Long. $35^{\circ} 35^{\prime}$ East and Lat. $32^{\circ} 50^{\prime}$ with a total surface area of about $170 \mathrm{~km}^{2}$ It is about $22 \mathrm{~km}$ long, $14 \mathrm{~km}$ wide, and an average depth of about 24m (Berman, 1998; ME-WDBP, 1998; Fig.2). Historically, the management of the lake has been changed from one convention to another. In the Sykes-Picot Agreement in 1916, which was between the governments of Britain and France, Syria had the full control over the lake. However, under the Convention of Obadr Clemenso, 1919, the lake was in Palestinian hands. While in the Treaty of San Remo in 1920 Syria had part of the lake and this part was redefined in the Paris treaty, 1920, to be one third of the lake. Yet, the 1923 treaty gave the whole lake to Palestine (Stas, 2008). The 1923 treaty had two contradictory articles; the first located the international border between Syria and Palestine $10 \mathrm{~m}$ east of the lakeshore. However, the second one gave Syria the right of using Tiberias Lake for navigation and fishing (Stas, 2008).

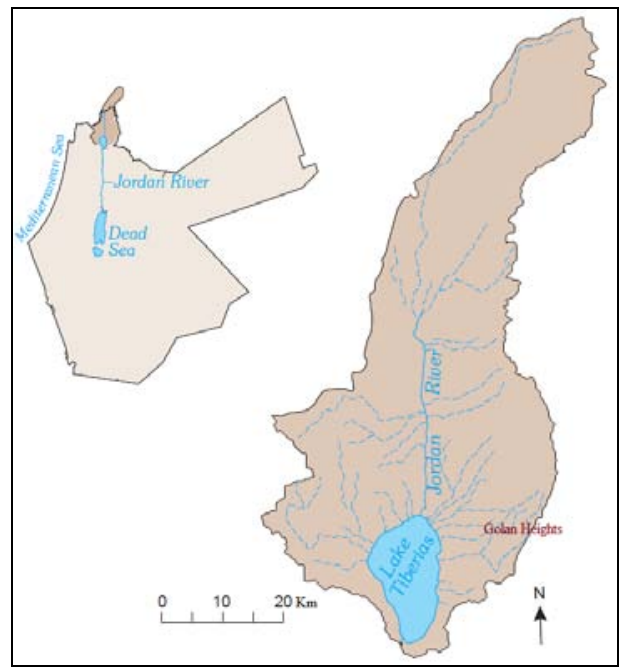

Figure 2.

Tiberias Lake (after ME-WDBP, 1998).

Due to the truce treaty (20 September, 1949) between Syria and Israel after the 1948 war, the international border was the shore of the lake. Syria had enjoyed using the eastern coast of the lake until the 1967 war, which is called the $4^{\text {th }}$ June 1967 line. Syria now wants to return to this border again. However, Israel has not agreed on this because if Israel withdraws to the $4^{\text {th }}$ June 1967 line it will grant 40 MCM/year to Syria (Schiff, 1993). The Clinton summit in Geneva on March 26, 2000, did not achieve any progress. It showed that the main obstacles were on access to the Tiberias Lake, the security arrangements, and the early-warning station (Migdalovitz, 2005). Yet, Israel cannot return the Golan Heights in order not to lose its control of springs, rivers, and Tiberias Lake (Humphries, 2006). Tiberias Lake, by the National Water Carrier System, provides about 
one-third of the Israeli freshwater needs (Tal, 2006). The lake receives $70 \%$ of its surface water from the northern Jordan River (Borisover, et al., 2009). There are three main rivers that contribute to $80 \%$ of the annual lake recharge through the Jordan River: Dan river 250 MCM; Banias river, which is located in the Syrian occupied land, supplies about 130 MCM about; and Hasbani river, which is located in Lebanese land, supplies about 130 MCM per year (Berman, 1998). According to Courcier et al. (2005), before 1950s Tiberias Lake together with Yarmouk River contributed to the Jordan River flow by 605 and 465 MCM per year, respectively. However, in 1970s, after the Israeli occupation of Palestinian land and the Golan heights and after constructing of the NWC, the picture changed completely (Table 1). Table 1 shows how the change affected the water sustainability of Tiberias Lake as well as the Jordan River flow and the Dead Sea, which at present only receives reclaimed water.

Table 1.

Water balance in Lake Tiberias

\begin{tabular}{|c|c|c|c|c|}
\hline \multicolumn{2}{|c|}{ Year } & 1950 s & $1970 s$ & $2000 s$ \\
\hline \multirow{2}{*}{$\begin{array}{c}\text { Inflow } \\
\text { (MCM) }\end{array}$} & Upper Jordan & 890 & 505 & 475 \\
\cline { 2 - 5 } & Yarmouk River & 0 & 45 & 65 \\
\hline \multirow{3}{*}{$\begin{array}{c}\text { Outflow } \\
\text { (MCM) }\end{array}$} & Evaporation & 285 & 285 & 285 \\
\cline { 2 - 5 } & NWC & 0 & 440 & 440 \\
\cline { 2 - 5 } & North Irrigation & 0 & 100 & 100 \\
\cline { 2 - 5 } & Jordan River & 605 & 65 & 35 \\
\hline \multicolumn{2}{|c|}{ Into the Dead Sea } & 1285 & 505 & 0 \\
\hline
\end{tabular}

\section{Results and Discussion from IWRM Perspective}

Recognizing IWRM principles, while resolving water conflicts, mean integrating all sectors in the negotiation process. This integration may balance interests between all parties and ensure stakeholder participation and the use of conflict management tools in the management process. Stakeholder participation should be at all levels that may affect water management decisions. Participation means being part of the process and accepting the need for change to ensure water sustainability, peace, and other water users' rights. Managing water by an integrated approach will solve water shortage by studying the situation taking into consideration water supply, water demand, water allocation, water socioeconomics, and water policy. In such an integrated climate new strategies can be built and new horizons can be opened. Below follows some specific aspects of IWRM that we believe would be especially important to consider for a successful application in the studied area. IWRM has four dimensions: water resources, water users, spatial scale, and temporal scales \& patterns (Savenije \& Van der Zaag, 2008). The discussion below follows these four dimensions.

\subsection{Water resources}

The first challenge that IWRM faces is quantifying the available water resources. According to FAO the annual renewable water availability per capita in the Middle East is decreasing due to population and development growth, the figures in 2025 will be about 60\% of those in 1970 (FAO, 2010). In addition to surface and groundwater, water resources include non conventional resources such as reclaimed, desalinated, and harvested waters. Treated wastewater is used all over the region for irrigation. Jordan plans to use reclaimed water discharged from about 36 wastewater treatment plants by 2013, 19 of them are currently working that produce about 72 MCM per year (Ammary, 2007). Syria has four plants and is planning to construct more than twenty new wastewater treatment plants. Extending the irrigation with treated wastewater could lead to significant water savings. Israel, on the other hand, produces an annual amount of about $500 \mathrm{MCM}$ of wastewater, 85\% of which were treated in 2008 (IWA, 2010). Greywater, which is water from showers, kitchen, and laundry, can be safely reused in agriculture. Jamrah et al. (2008) found that reusing greywater in Oman can save between 12 and 65\% of the total fresh water use. Greywater can also be used for toilet flushing and save between 29 to $35 \%$ of potable water (Ghisi \& Ferreira, 2007). In a study made in Sweida City, Syria, Mourad et al. (2011) found that the city can save about $35 \%$ of its drinking water if treated greywater is used for toilet flushing. Collecting and storing rainwater is generally named water harvesting. Water harvesting is a traditional method used throughout the Middle East to manage finite water supply. Indications of early water harvesting facilities constructed over 9000 years ago have been found in the Edom Mountains in southern Jordan (Nasr, 1999). Water from roofs can be stored and used in irrigation or for other uses. In Jordan, e.g., a maximum of $15.5 \mathrm{MCM} /$ year of rainwater can be collected from roofs of residential buildings considering that all rain falling on the surfaces is collected (Abdulla \& Al-Shareef, 2009), which represents about 7\% (231 MCM/year) of the total groundwater shortage in Jordan (MWI-JO, 2009). Syria can also save more than 35 million $\mathrm{m}^{3}$ of water by roof rainwater harvesting in rural areas (Mourad \& Bernedtsson, 2011) Water harvesting can also be done by collecting flood and stream water within a water basin in surface dams. These dams will enhance groundwater recharge and the harvested water can be used for irrigation or drinking water. Many areas in the rural Syria and Jordan already depend on these small dams for local water needs.

\subsection{Water users}

Water uses include: domestic, industry, agriculture, fisheries, ecosystems, hydropower, navigation, recreation, etc. For the domestic sector, the WHO minimum standard per capita water consumption is 100 Lpcd (liter per capita per day). The per capita of water consumption in the Middle East differs from country to country; it is 120 Lpcd for Syria, according to the Ministry of Housing and construction in Syria, 55 Lpcd for the Palestinian population (Abu Zahra, 2001), 190 Lpcd for Lebanon (El-Fadel, Zeinati, \& Jamali, 2000), and 225 Lpcd in IS (Portnov and Meir, 2008). Therefore, full consideration should be taken regarding water consumption for all riparian people to sustain their vital needs and to find new instruments for water demand management and water saving in order to reduce water losses within the water system and for domestic uses. Moreover, a field survey is very necessary to reflect the actual water consumption in these countries, which may lead to a vital need for a public awareness and/or rehabilitation of water systems. In this regard, countries can decrease domestic water consumption by introducing new water saving practices and techniques. Some water saving devices, which can be installed in water taps, can save more than 
$20 \%$ of the consumed water for washing and showers. Furthermore, the average toilet tank in the region is 9 LPF (liter per flush). A daily average per person of five times of using means daily consumed water in toilet flushing equal to 45 liter per person. However, installing a dual flush toilet, e.g., will reduce the flushed water to 21 liters, which means about $50 \%$ of the toilet water can be saved (VCI, 2002). The agricultural sector is the largest consumer of water in the Middle East (Table 2). Therefore great care should be taken towards increasing irrigation efficiency and selecting crops with small consumptive use.

Table 2.

Water use in some countries in the Middle East

\begin{tabular}{|c|c|c|c|c|}
\hline Water use (\%) & Syria & Jordan $^{1}$ & Lebanon $^{2}$ & Israel $^{3}$ \\
\hline Agriculture & 89 & 66 & 53 & 48 \\
\hline Domestic) & 8 & 29 & 24 & 35 \\
\hline Industry & 3 & 5 & 23 & 11 \\
\hline Other & - & - & - & 6 \\
\hline
\end{tabular}
(Ammary, 2007), ${ }^{2}$ El-Fadel et al. 2000), ${ }^{3 \text { (Dreizin et al. }}$

In this regard, acknowledging virtual water concept, which is the water embedded in producing any kind of good, can help countries in saving water. Banana production in Israel, e.g., consumes $1.4 \mathrm{~kg}$ of water per $\mathrm{kg}$ of banana (Pohoryles, 2000). Hence, taking into consideration that banana is not a vital crop for countries, it would be better for Israel to import banana instead of fighting its neighbors for water. Thus, countries in the region should use water to produce benefits that cannot be imported (Heinzen, 2001) and set their crop pattern according to gross profit per water use ratio. For example Jordan can save about $47 \mathrm{MCM}$ /year if farmers in the Jordan Valley change fruit trees to vegetables (Mourad, Gaese, \& Jabarin. 2010). Thus, new agricultural strategies may be recommended, within a regional cooperation, in order to reach higher water productivity and to suggest new allocation plans. Furthermore, the invisibility of the virtual water trade makes it extremely successful because it can be applied without political conflicts (Mourad, Gaese, and Jabarin. 2010).

\subsection{Spatial scale}

Although IWRM can be applied at local and national levels, it can also be applied at regional and international levels. On the other hand, the operational management inside the institutions should have interactions between all levels, which mean that the lower level interests should be taken into consideration at higher levels (Savenije \& Van der Zaag, 2008). Spatial scale includes allocation of water rights as well. (Zarour \& Isaac, 1992) proposed the following formula for the allocation of water rights in Tiberias Lake:

$$
\mathrm{S}_{\langle i\rangle}=50 *\left[\frac{\mathrm{B}_{(i)}}{\mathrm{B}_{(T)}}+\frac{\mathrm{I}_{(i)}-\mathrm{L}_{(i)}}{\mathrm{I}_{(T)}-\mathrm{L}_{(T)}}\right]
$$

where $S_{(i)}$ is the size of the right/obligation of state $i$ (percent); $B_{(i)}$ is the area of the basin/storage volume within or under the territory of state $i$; $B_{(T)}$ is the total area/storage volume of the basin; $I_{(i)}$ is the natural input to the basin originating within the territories of state $i ; I_{(T)}$ is the total input to basin $T$; $L_{(i)}$ is the natural loss from the basin's water occurring within the territories of state $i$; and $L_{(T)}$ is the total natural loss of water occurring throughout the basin.

The application of Eq. (1) needs data and cooperation between all parties to estimate correct parameter values, otherwise this may create new disputes between the counteracting parties. $B_{(i)}$ is the most important variable that should be agreed on. Israel wanted to retain a $400 \mathrm{~m}$ strip on the northern shore of the lake that means Israel will keep using the lake alone. Syria, on the other hand, wants to have access to the lake. A recent suggestion is that the northeastern shoreline could be a joint tourist area for Syrians, Israelis, and other international, under UN security supervision (Ma’oz, 2005).

\subsection{Temporal scales and patterns}

Acknowledging the temporal patterns of the water resources and the users means acknowledging floods, droughts, base flow, peak demands and other vital demands. This should constitute a basis for water demand management aiming at a better allocation of water resources. Moreover, water models should be used to predict best and worst water scenarios in order to set new strategies and plans that face future water scarcity problems, which will be a base for a better management of water balance between different hydrological years and different water basins.

\subsection{Application to Tiberias Lake}

The IWRM approach should be based on the previous dimensions. According to the international water law, riparian countries of a watercourse should include sustainability, optimal use, protection, and control of the water resources in their joint management plan (Elmusa, 1996). However, reviewing Eq. (1) shows an absence of the water sustainability term in the lake. In 2000, due to the Israeli water use, Tiberias Lake water level experienced an all-time low exceeding the red danger line. Besides the lake water level (Zaslavsky, 2000) indicated that the Israeli water use in the region was non-sustainable. Therefore, any suggested approach should take sustainability into consideration by taking the length of the water shores, the renewable amount of water that can be used, and the catchment areas and water amounts, in each country that contribute in feeding the lake into account.

Therefore, the IWRM approach will include many tasks; starting from the implementation of the United Nations resolutions, saving water to ensure its sustainability, concentrating on water productivity to get the optimal use regimes, and protecting water resources from environmental impact. The application of such approach needs full cooperation instead of confrontation between riparian countries at scientific and political levels. In such cooperative plan, basis for sustainable peace will be built. The following points can be a basis for an IWRM approach:

1- Implementation of the United Nations resolutions: As illustrated before Syria had the right to reach Tiberias Lake shore by the implementation of the Resolution 242 and 338, which is the first step towards any peace agreement.

2- Allocation of the Tiberias Lake water: Knowing that the total surface area of the lake is about $A=167 \mathrm{~km}^{2}$ and 
the total circumference of the lake is about $\mathrm{C}=53 \mathrm{~km}$, the surface area of the lake that can be used by Syria $A_{S}$ and Israel $A_{I}$, for fishing and swimming, depending on the regional circumference of the lake $\mathrm{C}_{\mathrm{S}}$ and $\mathrm{C}_{\mathrm{I}}$, can be computed by:

$$
\mathrm{A}_{\mathrm{S}, \mathrm{I}}=\mathrm{A} \times(\mathrm{Cs}, \mathrm{i} / \mathrm{C})
$$

For the discharged water, the Syrian and the Israeli share depends on the total catchment area, which is about $2730 \mathrm{~km}^{2}$ (ME-WDBP, 1998), and the feeding water amounts in each country, which means the higher the feeding amounts the higher the discharge rate, taking water sustainability into account. The average lake level is $210.4 \mathrm{~m}$ below sea level with an average range of about $1.3 \mathrm{~m}$ (ME-WDBP, 1998). Therefore, for the lake sustainability, it is advised to maintain this range. From (Berman, 1998) we can roughly estimate the Syrian share to be at least $20 \%$ of the total water discharge from the lake. The location of the intake and the exact amount need more studies and can be agreed on within a positive atmosphere.

3- Joint management plan: Creation of a joint management plan based on the participation of all sectors that deal with water at all levels. The negotiation within the plan should be interest-based and the main target of the plan could be water for peace. The following constitute a suggested line of action:

a. Protecting Tiberias Lake from negative environmental impact by formulating a joint environmental protection plan in order to suggest parameters for determination of water quality in the lake and to set water quality monitoring systems at the main inflow points. A regional water policy for Tiberias Lake catchment can help in protecting water quantity and quality in the lake for a better water management that can be enhanced by all stakeholders from Syria, Lebanon, Jordan, and Israel.

b. Proposing a greywater, water harvesting, and/or water saving devices project for four villages from Syria, Jordan, Lebanon, and Israel. The main objectives of the project would be to save domestic water by reusing greywater and harvested water in toilet flushing and in garden irrigation; and to estimate the potential saving from the implementation of water saving devices. Such projects could be funded by international organizations as it focuses on water for peace.

c. Analyzing the agricultural status in both countries trying to isolate wasteful crops by introducing the virtual water and water productivity concepts in the future agricultural plans without ignoring food security issues.

d. Merging water, energy, and economic issues. A feasibility study is needed to compare pumping water from Lake Tiberias, taking the distance and the elevation $210 \mathrm{~m}$ below sea level into account; with Construction of seawater desalination plant.

e. Taking local needs, priorities, and sustainability issues into account while planning any policy or project by enhancing the participatory approach.

4- Regional environmental plan that contains all stakeholders in the region aiming at maintaining Jordan River, which flow at present, is almost non-existent.
With such an approach Middle East countries will have new target to focus on instead of gunfire. New projects can be implemented and new targets can be achieved, which can create new future to the region at national, regional, and international horizons.

\section{Conclusions}

Based on the foregoing, gunfire cannot provide drinking water to thirsty people, nor can it solve the present water crisis in the Middle East. Money that is used for arming the region can be used for improving the regional situation. Therefore, policy makers may think in reforming their policies depending on the real situation. What is needed is a new emphasis on cooperation for the establishment of a regional water policy, to advocate cooperation instead of confrontation and integration instead of fragmentation, which cannot be achieved before reaching a complete and comprehensive peace based on the United Nations resolutions.

The historical records about the international borders between Syria and Israel show that Syria has the right to use Tiberias Lake. However, the size of this right and the purposes should be agreed on within a framework under the United Nations supervision and a positive negotiation atmosphere. Construction of a sew water desalination plant may decrease the area's water stress and may also improve the environmental characteristics of the Jordan basin. A fruitful interest-based negotiation process aiming at solving the actual water problems in the region can be the base for water sustainability and peace in the region.

Integrated water resources management is an approach to solve the water shortage in the Middle East by acknowledging the participatory approach, the environmental characteristics of the region, and recognizing water best practices in irrigation and in potable water saving. The integration of sectors and stakeholders at a regional level should be based on cooperation and transparency. The cooperation should be built on scientific basis in order to save water by carrying out water and agricultural research that focus on virtual water, reclaimed water, water saving techniques, and new water allocation strategies aiming at saving water resources at the regional level to put a joint management plan. In such cooperative plan, withdrawing to the 4th June 1967 borderline will create new future to the region. It will direct all efforts towards a sustainable peace.

\section{Acknowledgements}

Funding from the MECW project at the Center for Middle Eastern Studies, Lund University, is gratefully acknowledged.

\section{REFERENCES}

Abdulla, F. A. \& Al-Shareef, A.W. (2009). Roof rainwater harvesting systems for household water supply in Jordan. Desalination, 243, 195-207.

Abu Zahra, B. A. (2001). Water crisis in Palestine'. Desalination, 136, 93-99.

Ammary, Y. B. (2007). Wastewater reuse in Jordan: Present status and future plans. Desalination, 21, 164-176. 
Berman, T. (1998). Lake Kinneret and its catchment: international pressures and environmental impacts. Water Policy, 1, 193-207.

Borisover, M., Laor, Y,, Parparov, A., Bukhanovsky, N. \& Lado, M. (2009). Spatial and seasonal patterns of fluorescent organic matter in Lake Kinneret (Sea of Galilee) and its catchment basin. Water Research, 43, 3104 - 3116.

Brooks, D. B. \& Lonergan, S. C. (1994). Watershed: The Role of Fresh Water in the Israeli-Palestinian Conflict, International Development Research Centre: Ottawa Canada K1G 3H9. URL (last checked 12 February 2010) http://www.idrc.ca/openebooks/719-1/

Cooley, J. (1984). The war over water. The war over water. Foreign Policy, 54, 13-26.

Courcier, R., Venot, R. \& Molle, J. P. (2005). Historical transformations of the lower Jordan river basin (in Jordan): Changes in water use and projections (1950-2025). International Water Management Institute Colombo, Sri Lanka: 91p. URL (last checked 12 January 2011)

http://www.iwmi.cgiar.org/assessment/files_new/publications/C A\%20Research\%20Reports/ColouredCARR9.pdf

Daoudy, M. (2008). A missed chance for peace Israel and Syria's negotiation over the Golan Heights. Journal of International Affairs, 61,215-234.

Dreizin, Y., Tenne, A. \& Hoffman, D. (2008). Integrating large scale seawater desalination plants within Israel's water supply system. Desalination, 220, 132-149.

El-Fadel, M., Zeinati, M. \& Jamali, D. (2000). Water resources in Lebanon: Characterization, water balance and constraints. Water Resources Development, 16, 619-642.

Elmusa, S. S. (1993) Dividing the common Palestinian Israeli waters: an international water law approach. Journal of Palestine Studies, 57, 57-58.

Elmusa, S. S. (1996). Negotiating Water: Israel and the Palestinians. Working paper from the Institute For Palestine Studies. URL (last checked $11 \quad$ October 2010) http://www.ciaonet.org/wps/els01/index.html

FAO. (2010). Food and Agriculture Organization. Aquastat database. URL (last checked 15 December 2010) http://www.fao.org/nr/water/aquastat/main/index.stm

Funke, N., Oelofse, S. H. H., Hattingh, J., Ashton, P.J. \& Turton, A. R. (2007). IWRM in developing countries: Lessons from the Mhlatuze Catchment in South Africa. Physics and Chemistry of the Earth, 32, 1237-1245.

Ghisi, E. \& Ferreira, D. F. (2007). Potential for potable water savings by using rainwater and greywater in a multi-storey residential building in southern Brazil'. Building and Environment, 42, 2512-2522.

Haddadin, I. M. (2002). Water in the Middle East peace process'. The Geographical Journal, 168, 324-340.

Hewedy, A. (1989). Militarization and Security in the Middle East: Its Implications on Development and Democracy, London.

Heinzen, B. (2001). Conference report: 4.7 Water for peace in the Middle East. Water Policy, 3, S153-S154.

Humphries, I., (2006). Breaching Borders: The Role of Water in the Middle East Conflict, Washington Report on Middle East Affairs;Sep/Oct2006, 25, p20. URL (last checked 3 February 2013) http://connection.ebscohost.com/c/articles/22069382/breaching-b orders-role-water-middle-east-conflict

Jamrah, A., Al-Futaisi, A., Prathapar, S. \& Al-Harrasi, A. (2008). 'Evaluating greywater reuse potential for sustainable water resources management in Oman. Environmental Monitoring and Assessment, 137, 315-327.

Juizo, D., Liden, R. \& Vaz, C. A. (2006). Remaining challenges for bi national on shared water: the Umbeluzi case. Water Policy, 8, 231-253.

Jägerskog, A. (2003). Why states cooperate over shared water: The water negotiations in the Jordan River Basin, Department of Water and Environmental Studies, Linköping Univerity, Sweden. URL (last checked 10 April 2010) http://www.transboundarywaters.orst.edu/publications/related_re search/jagerskog2003.pdf

Ma’oz, M. (2005). Can Israel and Syria reach peace? Obstacles, lessons and prospects, the James a. Baker III Institute for Public
Policy Rice University. URL (last checked 11 March 2011) http://www.bakerinstitute.org/publications/wp_israelsyria.pdf

ME-WDBP. (1998). Middle East Water Data Banks Project, Overview of Middle East Water Resources. URL (last checked 1 December 2010) http://exact-me.org/overview/p31.htm

Migdalovitz, C. (2005). The Middle East Peace Talks, CRS Issue Brief for Congress IB91137. URL (last checked 11 March 2011) http://shelby.senate.gov/legislation/MiddleEast.pdf

Mimi, A. Z. and Sawalhi, B. (2003). A Decision Tool for Allocating the Waters of the Jordan River Basin between all Riparian Parties. Water Resource Management, 17, 447-461.

MOI-SY, (2008). Ministry of Irrigation in Syria. URL (last checked 11 December 2010) http://www.irrigation.gov.sy/

Mourad, A. K, Gaese, H. \& Jabarin, S. A. (2010) 'Economic value of tree fruit production in Jordan Valley from a virtual water perspective', Water Resource Management, Vol. 24, pp.2021-2034.

Mourad, A. K. , Berndtsson, J. C., \& Berndtsson, R. (2011). Potential fresh water saving using greywater in toilet flushing in Syria, Journal of Environmental Management, 92, 2447-2453.

Mourad, A.K., \& Berndtsson, R. (2011). Potential water saving from rainwater harvesting in Syria. Journal of Water Management and Research, 67, 113-117.

Murakami, M. (1995). Managing water for peace in the Middle East: Alternative strategies. Tokyo: United Nations University Press. URL (last checked 20 February 2011) http://library.northsouth.edu/Upload/Managing\%20Water\%20for \%20Peace.pdf

MWI-JO. (2009). (Ministry of Water and Irrigation in Jordan). URL (last checked 20 November 2010) http://www.mwi.gov.jo/Dashboard.aspx

Nasr, M. (1999). Assessing Desertification and Water Harvesting in the Middle East and North Africa: Policy Implications. Discussion Papers on Development Policy, Zentrum für Entwicklungsforschung (ZEF). Bonn. URL (last checked 27 May 2011) http://www.zef.de/fileadmin/webfiles/downloads/zef_dp/zef_dp1 0-99.pdf

Petit, O. \& Baron, C. (2009). Integrated Water Resources Management: From general principles to its implementation by the state. The case of Burkina Faso. Natural Resources Forum, 33, 49-59.

Pohoryles, S. (2000). Program for Efficient Water Use in Middle East Agriculture. In: Water for Peace in the Middle East and Southern Africa, Green Cross International. URL (last checked $27 \quad$ May 2011) http://www.hidropolitik.hacettepe.edu.tr/middleeast.pdf

Portnov, B. A. \& Meir, I. (2008). Urban water consumption in Israel: convergence or divergence?, Environmental Science \& Policy, 11, 347-358.

Rahaman, M. M. \& Varis, O. (2005). Integrated water resources management: Evolution, prospects and future challenges, Sustainability: Science, Practice \& Policy, 1, 15-21.

Savenije, H. H. G. \& Van der Zaag, P. (2008) 'Integrated water resources management: Concepts and issues’, Physics and Chemistry of the Earth, Vol. 33,pp. 290-297.

Schiff, Z. (1993). Peace with Security: Israel's minimal security requirements in negotiations with Syria . Washington, D.C.

Smith, C.G. (1966). The disputed waters of the Jordan, Transactions of the Institute of British Geographers. Vol.40,pp.111-128.

Starr, J. R. \& Stoll, D. C. (1987) U.S. Foreign Policy on Water Resources in the Middle East, D.C.

Stas, E. A. (2008) Arabic document> وإثكالية الحدود السورية الفلسطينية وقضم أر اضي الجولان . . URL (last checked 23 September 2010) http://www.voltairenet.org/article157843.html

Tal, A. (2006). Seeking sustainability: Israel's evolving water management strategy', Science, 313, 1081-1084.

VCI. (2002). Veritec Consulting Inc. Dual-flush Toilet Project. Canada Mortgage and Housing Corporation. URL (last checked 23 September 2010) http://www.allianceforwaterefficiency.org/

Wolf, T. A. (1996) Middle East Water Conflicts and Directions for Conflict Resolution, Food, Agriculture, and the Environment Discussion Paper 12, International Food Policy Research Insti- 
tute. Washington, USA. URL (last checked 23 September 2010) http://www.agedhq.org/ffe/pdffiles/pdf08/mewcdfcr.pdf

Workman, T. (1991) The Social Origins of The Iran-Iraq War, Centre for International and Strategic Studies York University. URL (last checked 11 January 2011) http://www.yorku.ca/yciss/publications/WP05-Workman.pdf

Zarour, H., \& Isaac, J. (1992) 'Nature's apportionment and the open market: a promising solution convergence to the Arab-Israeli water conflict'. Paper Presented at the Conference on the Middle East Water Crisis. Creative Perspectives and Solutions. 8-9 May 1992. University of Waterloo, Waterloo, ON, Canada.

Zaslavsky, D. E. (2000). Definition of Israel's Water Problems or Water as a Metaphor, Lecture Presented at Bar-Ilan University on the occasion of the inauguration of an Interdisciplinary
Project entitled "Efficient Use of Limited Water Resources: Making Israel a Model State" in the Begin-Sadat Center for Strategic Studies, sponsored by Soda-Club Ltd., Israel. URL (last checked 4 February 2013)

http://www.biu.ac.il/SOC/besa/water/zaslavsky.html

Zeitoun, M., \& Mirumachi, N. (2008). Transboundary water interaction I: reconsidering conflict and cooperation, International Environmental Agreements, 8, 297-316.

Zeitoun, M., Messerschmid, C., \& Attili, S (2009). Case Study/Asymmetric Abstraction and Allocation: The Israeli-Palestinian Water Pumping Record, Ground Water, 47, 146-160. 